\title{
Discoloration on Methylene Blue Solutions by Direct and Catalytic Ozonation
}

\author{
Antonio D. Rodriguez-Lopez ${ }^{{ }^{*}}$, Jose Garcia-Garrido ${ }^{1 *}$, Cynthia Perez-Ramiro ${ }^{1}$, \\ Esperanza M. Garcia-Castello ${ }^{2}$ \\ ${ }^{1}$ Grupo de Tecnologías de Control de Aguas y Residuos (TECAR), Universitat Politècnica de València, \\ Camino de Vera, Valencia, Spain \\ ${ }^{2}$ Institute of Food Engineering for Development, Universitat Politècnica de València, \\ Camino de Vera, Valencia, Spain \\ Email: *anrodlo@iqn.upv.es, *jgarciag@iqn.upv.es
}

Received August 2013

\begin{abstract}
During textile manufacturing, huge amounts of wastewaters characterized by removed impurities and high concentrations of dye are produced. These wastewaters cause several problems when they are discharged to the environment. The use of ozone in wastewater treatment results of interest. In this work we propose to assess the discoloration rate of different synthetic wastewaters as a function of $\mathrm{pH}$, dye concentration (methylene blue (MB)) and reaction time. A comparison of discoloration rate between conventional ozonation and catalytic ozonation salts of copper, zinc, silver and nickel was also performed. For the optimization of the ozonation process of colored solutions, it was used a central composite experimental design with five replicates of the center point resulting to evaluate the influence of the independent variables at different ranges of $\mathrm{pH},[\mathrm{MB}]$ and time. In the catalyst-assisted ozonation, [MB], $\mathrm{pH}$ and the reaction time were fixed to $100 \mathrm{mg} / \mathrm{L}, 5.5$ and $15 \mathrm{~min}$, respectively. The optimized experimental conditions to provide maximum discoloration were $\mathrm{pH}=3.3$; $[\mathrm{MB}]=8.6 \mathrm{mg} / \mathrm{L}$ and time $=74.3 \mathrm{~min}$. Regarding the catalyst-assisted ozonation, it was found that $\mathrm{CuSO}_{4}$ catalyst gave better color reduction if compared with other catalysts assayed.
\end{abstract}

Keywords: Textile Wastewater; Methylene Blue; Discoloration; Ozonation; Catalytic

\section{Introduction}

Textile industry is one of the most common and essential sectors in the world [1]. It is considered one of the longest and most complex manufacturing industrial chains, covering the entire production cycle from raw materials to semi-processed products (yarns, woven and knitted fabrics with theirfinishing process), and final products (carpets, home textiles, clothing and industrial use textiles) [2,3]. At the EU, the over the $80 \%$ of the textile production are headed by Italy, Germany, UK, France and Spain [2].

During the textile manufacturing, huge amounts of water as well as chemical products are consumed [4]. Hence, wastewaters are characterized by their high volume, removed impurities and high concentrations of dye. In this sense, from $30 \%$ [5] to 50\% [6] of the dye used in the textile processing are present mainly as hydrolyzed in wastewaters.

Textile wastewaters cause several problems when they are discharged to the environment due to color provided

${ }^{*}$ Corresponding authors. by dyes. There are esthetic problems $[2,3,5,6]$ as well as toxic problems to aquatic life since colored wastewaters avoid the light penetration and in addition, dyes or their derivatives present harmful properties [1,5,7].

Therefore, color removal must be one of the targets to treat both textile dyeing and dye manufacture wastewaters $[8,9]$. Physicochemical and biological treatments of these wastewaters have been proposed. Conventional physicochemical processes are effective to remove dyes $[10,11]$, but are expensive [3,12]. Another drawback is that physicochemical treatments transfer the pollutants to other phase but not eliminate the problem [13]. The accumulation of toxic compounds in the sludge can create disposal problems that might also lead to a secondary pollution [3,11,12].

Biological treatments are considered not to be completely adequate. In textile wastewater, there are resistant pollutants to biological degradation, and so, color is reduced but not up to levels that allow direct discharge $[3,6,7,11,13,14]$.

Other alternatives for the textile wastewater color removal are anaerobic treatments [5], activated carbon [11], 
combined processes as fluidized biofilm process-chemical coagulation-electrochemical oxidation [15] or activated carbon and sequencing batch reactor (SBR) [12]. However studies and investigations on other options of wastewater treatments such as ozonation or advanced oxidation processes (AOPs) are necessary to remove the color completely [3].

The use of ozone in wastewater treatment results of interest because there is no sludge production; the performance is very easy; the required space is small and residual ozone can be easily decomposed to oxygen and water [13]. Regarding the AOPs, they are based on the generation of hydroxyl radicals in water. These radicals are highly reactive and nonselective oxidants that can oxidize different organic compounds [13].

Most studies about AOPs are focalized in photocatalytic oxidation, Fenton (FO), photo-Fenton and ozone oxidation have been attempted individually or combined with $\mathrm{UV}, \mathrm{TiO}_{2}$ or $\mathrm{H}_{2} \mathrm{O}_{2}$ oxidants to decolorize the textile wastewater $[1,13,16-19]$ but there are no many studies to treat to decolorate with ozone and other catalyst as copper, zinc, silver or nickel [20].

In this work we propose to assess the discoloration rate of different synthetic wastewaters as a function of $\mathrm{pH}$, dye concentration (methylene blue (MB) [9]) and reaction time. A comparison of discoloration rate between conventional ozonation and catalytic ozonation salts of copper, zinc, silver and nickel was also performed.

\section{Introduction}

\subsection{Chemicals}

The substrate of the reaction, methylene blue $\left(\mathrm{C}_{16} \mathrm{H}_{18} \mathrm{ClN}_{3} \mathrm{~S} \cdot(2-3) \cdot \mathrm{H}_{2} \mathrm{O}\right.$; MW $319.9 \mathrm{~g} / \mathrm{mol}$ (d.b.)), was purchased from Prolabo (VWR Prolabo, Fontenay-sousBois, France), was employed without further purification. Zinc oxide (ZnO), copper (II) sulfate pentahydrate $(\mathrm{Cu}-$ $\mathrm{SO}_{4} \cdot 5 \mathrm{H}_{2} \mathrm{O}$ ), potassium iodide (KI), sodium hydroxide $(\mathrm{NaOH})$ and sulfuric acid $\left(\mathrm{H}_{2} \mathrm{SO}_{4}\right)$ were obtained from Prolabo too.

Other reagents, as Zinc sulfate heptahydrate $\left(\mathrm{ZnSO}_{4} \cdot 7 \mathrm{H}_{2} \mathrm{O}\right)$, titanium dioxide $\left(\mathrm{TiO}_{2}\right)$, nickel (II) sulfate hexahydrate $\left(\mathrm{NiSO}_{4} \cdot 6 \mathrm{H}_{2} \mathrm{O}\right)$, copper (II) sulfate anhydrous $\left(\mathrm{CuSO}_{4}\right)$ and silver sulfate $\left(\mathrm{AgSO}_{4}\right)$ were purchased from Merck (Darmstadt, Germany).

\subsection{Ozonation System}

The laboratory system used is depicted in Figure 1. It consisted in two columns: the first column (ozonation reactor) was a PVC pipe with a diameter of $3.5 \mathrm{~cm}$ and a height of $1 \mathrm{~m}$. The experimental volume was fixed at 500 $\mathrm{mL}$ and presented an outlet at the bottom for the sample extraction, as well as an upper connection to the second column for the outflow of ozone in excess.

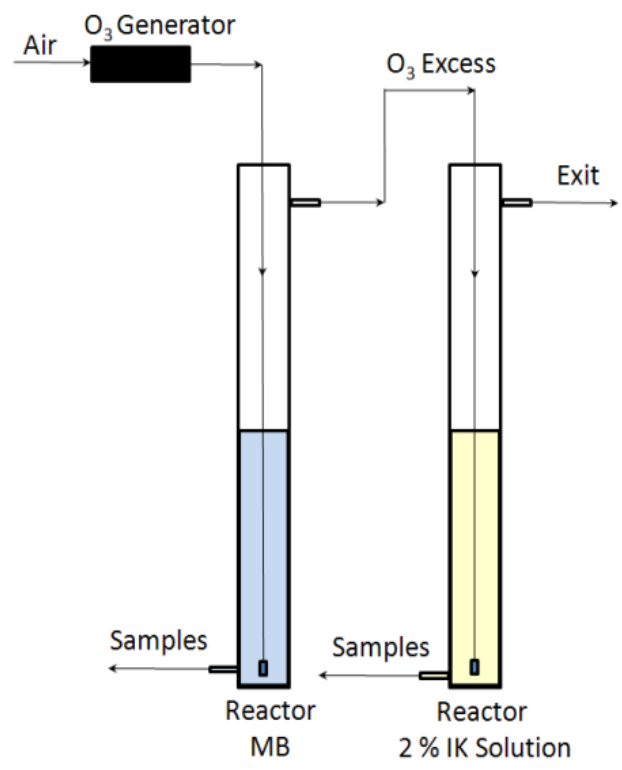

Figure 1. Schematic diagram of reactor system.

This second reactor, with the same dimensions and volume than the first one contained a solution of $2 \%$ IK.

Ozone was generated directly from oxygen in air by a G300 Hidro device (ZonoSistem, Cádiz, Spain). The average gas flow generated was $0.76 \mathrm{~L} / \mathrm{min}$, with an average generation rate of $0.86 \mathrm{mg} \mathrm{O} / \mathrm{min}$, thus, the $\mathrm{O}_{3}$ concentration in the inlet of the first reactor inlet was $1.14 \mathrm{mg} / \mathrm{L}$.

\subsection{Experimental Design}

\subsubsection{Direct Ozonation Process}

For the optimization of the ozonation process of colored solutions, it was used a central composite (CCD) experimental design with five replicates of the center point resulting in a 19 runs to evaluate the influence of the independent variables at different ranges: $\mathrm{pH}(3.3$ - 11.7), methylene blue concentration (7.9 - $92.0 \mathrm{mg} / \mathrm{L}$ ) and reaction time (9.5 - $110.4 \mathrm{~min})$. Natural and coded variables are shown in Table 1. The response considered was the final absorbance in order to calculate the color reduction.

The effect of these three independent variables on color reduction was studied trough a Response Surface Methodology (RSM). The use of RSM is useful for modeling and analysing when a response is influenced by several variables and the objective is to optimize this response [21].

\subsubsection{Catalyst-Assisted Ozonation Process}

In the catalyst-assisted ozonation, the laboratory system, the MB solution volume and the ozone concentration were the same than used in the direct ozonation. The MB concentration, $\mathrm{pH}$ and the reaction time were fixed to $100 \mathrm{mg} / \mathrm{L}, 5.5$ and $15 \mathrm{~min}$, respectively. 
Table 1. Natural and coded (in brackets) variables for the experimental factors $\mathrm{pH}$, Methylene Blue concentration and reaction time in the central composite design for the direct ozonation of organic dye solutions.

\begin{tabular}{|c|c|c|c|}
\hline Run & $\mathrm{pH}\left(\mathrm{X}_{1}\right)$ & {$[\mathrm{MB}](\mathrm{mg} / \mathrm{L})\left(\mathrm{X}_{2}\right)$} & $\mathrm{t}(\min )\left(\mathrm{X}_{3}\right)$ \\
\hline 1 & $10(+1)$ & $25(-1)$ & $90(+1)$ \\
\hline 2 & $5(-1)$ & $75(+1)$ & $90(+1)$ \\
\hline 3 & $7.5(0)$ & $50(0)$ & $60(0)$ \\
\hline 4 & $7.5(0)$ & $50(0)$ & $110.4(+1.68)$ \\
\hline 5 & $7.5(0)$ & $50(0)$ & $9.5(-1.68)$ \\
\hline 6 & $5(-1)$ & $25(-1)$ & $30(-1)$ \\
\hline 7 & $11.7(+1.68)$ & $50(0)$ & $60(0)$ \\
\hline 8 & $7.5(0)$ & $92(+1.68)$ & $60(0)$ \\
\hline 9 & $7.5(0)$ & $50(0)$ & $60(0)$ \\
\hline 10 & $5(-1)$ & $75(+1)$ & $30(-1)$ \\
\hline 11 & $7.5(0)$ & $8(-1.68)$ & $60(0)$ \\
\hline 12 & $3.3(-1.68)$ & $50(0)$ & $60(0)$ \\
\hline 13 & $7.5(0)$ & $50(0)$ & $60(0)$ \\
\hline 14 & $5(-1)$ & $25(-1)$ & $90(+1)$ \\
\hline 15 & $10(+1)$ & $75(+1)$ & $30(-1)$ \\
\hline 16 & $7.5(0)$ & $50(0)$ & $60(0)$ \\
\hline 17 & $10(+1)$ & $75(+1)$ & $90(+1)$ \\
\hline 18 & $10(+1)$ & $25(-1)$ & $30(-1)$ \\
\hline 19 & $7.5(0)$ & $50(0)$ & $60(0)$ \\
\hline
\end{tabular}

Several catalyst were assessed $\left(\mathrm{ZnO}, \mathrm{CuSO}_{4} \cdot 5 \mathrm{H}_{2} \mathrm{O}\right.$, $\mathrm{CuSO}_{4}, \mathrm{AgSO}_{4}, \mathrm{NiSO}_{4} \cdot 6 \mathrm{H}_{2} \mathrm{O}, \mathrm{TiO}_{2}$ and $\mathrm{ZnSO}_{4} \cdot 7 \mathrm{H}_{2} \mathrm{O}$ ). Different doses of catalyst were evaluated $(0,2,20$ and $200 \mathrm{mg} / \mathrm{L}$ ). To study the evolution of the discoloration rate with time, samples were taken each 5 min.

\subsection{Analytical Determinations}

\subsubsection{Ozone Measurement}

The ozone concentration was determined by bubbling the gas generated in a solution of IK, $\mathrm{Na}_{2} \mathrm{HPO}_{4}$ and $\mathrm{KH}_{2} \mathrm{PO}_{4}$ to $2 \%, 0.73 \%$ and $0.35 \%$, respectively, and subsequent titration with sodium thiosulfate $0.002 \mathrm{M}$ daily prepared $[22,23]$.

\subsubsection{Discoloration Rate}

The discoloration rate or color reduction was determined as expressed in Equation (1). The absorbance was meas- ured in a Genesys 5 spectrophotometer (Spectronic Instruments, USA) at the maximum wavelength for the Methylene Blue (665 nm) [6,7].

$$
\operatorname{Rcolor}(\%)=\frac{A b s_{f}-A b s_{0}}{A b s_{o}} \times 100 \%
$$

where $\mathrm{Abs}_{\mathrm{f}}$ is the absorbance at requested time and $\mathrm{Abs}_{0}$ is the initial absorbance of each solution.

\subsection{3. pH Measurement}

The $\mathrm{pH}$ of the different solutions was measured by a pH-meter (pH \& ION meter GLP 22, Crison, Spain). The $\mathrm{pH}$ of the feed solutions shown in Table 1, were adjusted by using $0.1 \mathrm{M} \mathrm{NaOH}$ and $0.1 \mathrm{M} \mathrm{H}_{2} \mathrm{SO}_{4}$.

All the analyses were done in triplicate. Data used in the statistical analysis were the average of these three values. Results were analyzed using the software "Statgraphics" version Centurion XVI, from StatPoint Technologies, Inc, USA. Linear and quadratic effects of the three variables considered, as well as their interactions on the response variables studied were calculated. Their significance was evaluated by analysis of variance (ANOVA). The proposed model, to which the experimental data were fitted, was a second-order polynomial model (Equation (2)).

$$
Y=\beta_{0}+\sum_{i=1}^{n} \beta_{i} X_{i}+\sum_{i=1}^{n} \beta_{i i} X_{i}^{2}+\sum_{j=i+1}^{n} \beta_{i j} X_{i} X_{j}
$$

where $\mathrm{Y}$ is the response variable; $\beta_{0}, \beta_{\mathrm{i}}$ ( $\left.\mathrm{i}=1,2,3\right), \beta_{\mathrm{ij}}$ (I $=1,2,3 ; \mathrm{j}=1,2,3)$ and $\beta_{\mathrm{iii}}(\mathrm{i}=1,2,3)$ are the coefficients for independent, linear, interaction and quadratic terms, respectively.

\section{Results and Discussion}

\subsection{Direct Ozonation Process}

Experimental results shown that the color reduction presented values higher than 95\% in all runs excepting for the run 5 in which the reaction time was the lowest assayed (9.5 min). Thus, it seems that at times considered in the experimental design proposed, the color reduction evolution has been missed. From reaction time higher than $60 \mathrm{~min}$, the reduction color presented an asymptotic trend close to $100 \%$ (Figure 2).

Results obtained in terms of color reduction by direct ozonation were fitted to a second-order polynomial model (Table 2).

For a confidence level of 95\%, the p-value of the significant effects must be lower than 0.05 . It was found that the significant terms were linear and quadratic terms corresponding to the time reaction (positive and negative effect, respectively). The RSM plot for the color reduction is depicted in Figure 2. There is a reduction of the color reduction as the MB concentration increases. 


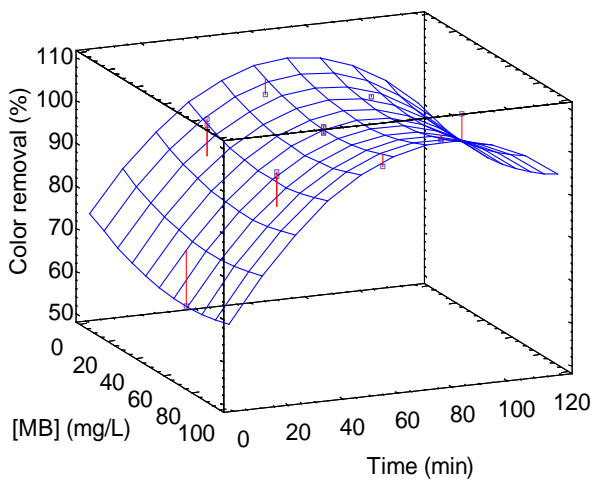

Figure 2. Response surfase plot for the color reduction as a function of the Methylene blue concentration and time. The pH was fixed at 7.5.

Table 2. Second-order model equation for the response surface fitted to the experimental data points obtained in the direct ozonation of organic dye solutions as a function of pH (1), NaCl concentration (2) and time (3).

\begin{tabular}{cc}
\hline Coefficient & Rcolor \\
\hline Independent & \\
$\beta_{0}$ & 82.06410 \\
Linear & \\
$\beta_{1}$ & -2.47667 \\
$\beta_{2}$ & -0.22735 \\
$\beta_{3}$ & 0.89928 \\
Quadratic & \\
$\beta_{12}$ & -0.00102 \\
$\beta_{13}$ & -0.00405 \\
$\beta_{23}$ & 0.00078 \\
Crossproduct & \\
$\beta_{11}$ & 0.18457 \\
$\beta_{22}$ & 0.00177 \\
$\beta_{33}$ & -0.00604 \\
$\mathrm{R}^{2}$ & 67.5 \\
\hline
\end{tabular}

It was found that for experimental conditions of $\mathrm{MB}$ concentration $50 \mathrm{mg} / \mathrm{L}$ and reaction time $60 \mathrm{~min}$, the color reduction reaches values close to $100 \%$, regardless the $\mathrm{pH}$ assayed. Thus, $\mathrm{pH}$ is the experimental variable that presents less influence on the color reduction. According to the obtained model, it was possible to optimize the experimental conditions that should provide maximum values of color reduction. These experimental conditions were: $\mathrm{pH}=3.3$, $\mathrm{MB}$ concentration $=8.6 \mathrm{mg} / \mathrm{L}$ and reaction time $=74.3 \mathrm{~min}$. The expected color reduction would be $107 \%$. Under a physical point of view, this mathematical value implies a total color reduction. In order to validate the optimization proposed, an extra experiment was done under the optimum conditions. The color reduction obtained was $99.4 \%$, what means a deviation of the optimum expected value of $0.6 \%$.

\subsection{Catalyst-Assisted Ozonation Process}

Figure 3 shows the absorbance evolution with the time reaction course for all the catalysts assayed as well as for an experiment without any catalyst to make the proper comparison. Initial absorbances at $665 \mathrm{~nm}$ for all experiments are in a range of (12.57 - 13.27), this small dispersion was expected since at $t=0$, the absorbance should be the absorbance that presents the MB feed solution of $100 \mathrm{mg} / \mathrm{L}$. Evolution with all catalysts follows the same decreasing trends but with different slopes.

The reduction color of the MB feed solution with time is depicted in Figure 4. Catalyst that showed lowest color reduction response after 15 min was $\mathrm{CuSO}_{4} \cdot 5 \mathrm{H}_{2} \mathrm{O}$, whilst the best catalyst at the end of the treatment is by far, the $\mathrm{CuSO}_{4}$.

When no catalyst was used, the color reduction is located among values obtained by catalysts until a reaction time of $10 \mathrm{~min}$, afterwards, the color reduction shown is clearly lower except by the experiment with $\mathrm{CuSO}_{4} \cdot 5 \mathrm{H}_{2} \mathrm{O}$.

Once the experiment was over, the highest color reduction was shown by the $\mathrm{CuSO}_{4}$ reaching values up to $68.5 \%$. Regarding the color reduction shown by the experiment without catalyst (only with ozone) the maximum values were $41.0 \%$. Comparing both maximum color reduction with $\mathrm{CuSO}_{4}$ catalyst and without catalyst, it was found differences of color reduction of about $67.1 \%$ for the $\mathrm{CuSO}_{4}$ catalyst. Catalyst doses assayed had a determinant effect on the color reduction after 15 min of reaction time (Figure 5).

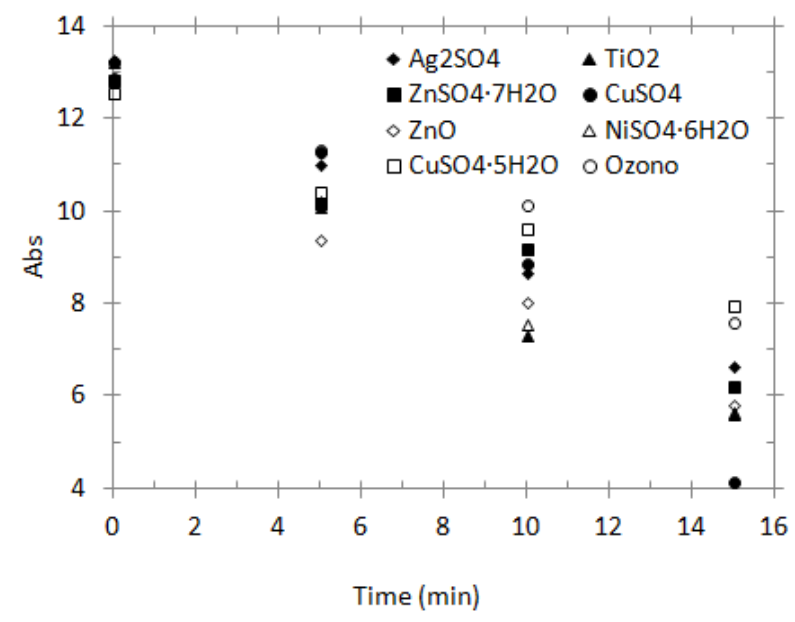

Figure 3. Absorbance variation with the reaction time course with differents catalysts and without catalyst. Catalyst dose fixed at $200 \mathrm{mg} / \mathrm{L}$. 


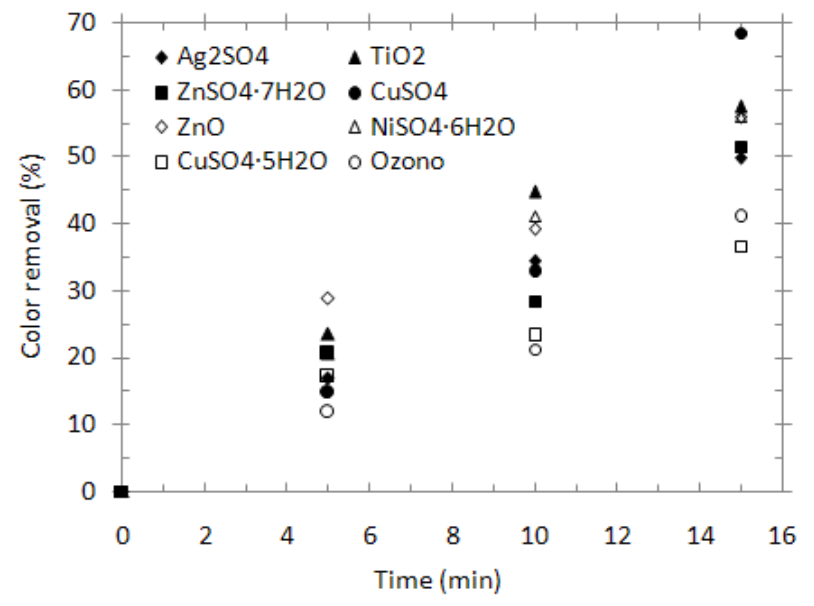

Figure 4. Color reduction variation with the reaction time course with differents catalysts and without catalyst. Catalyst dose fixed at $200 \mathrm{mg} / \mathrm{L}$.

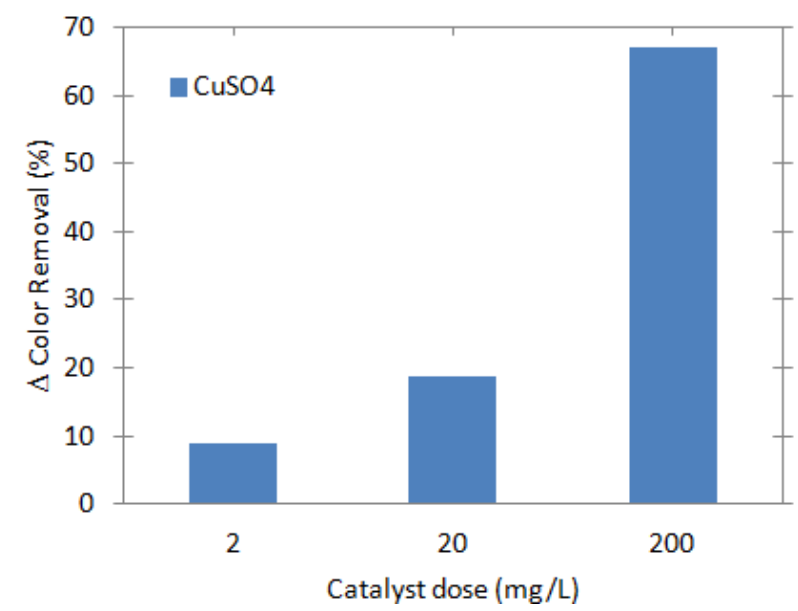

Figure 5. Effect of the $\mathrm{CuSO}_{4}$ catalyst dose on the color reduction.

\section{Conclusions}

For the direct ozonation treatment, variables studied $(\mathrm{pH}$, [MB], t) had different effects on discoloration rate. Time was the most significant variable and $\mathrm{pH}$ presented lowest influence on color reduction. The optimized experimental conditions to provide maximum discoloration $(\mathrm{pH}$ $=3.3$; $[\mathrm{MB}]=8.6 \mathrm{mg} / \mathrm{L}$ and time $=74.3 \mathrm{~min}$ ) were successfully validated with a deviation of $0.6 \%$.

Regarding the catalyst-assisted ozonation, it was found that $\mathrm{CuSO}_{4}$ catalyst gave better color reduction if compared with other catalysts assayed $\left(\mathrm{CuSO}_{4}>\mathrm{TiO}_{2}>\mathrm{Ni}-\right.$ $\mathrm{SO}_{4} \cdot 6 \mathrm{H}_{2} \mathrm{O}>\mathrm{ZnO}>\mathrm{ZnSO}_{4} \cdot 7 \mathrm{H}_{2} \mathrm{O}>\mathrm{Ag}_{2} \mathrm{SO}_{4}>\mathrm{Cu}-$ $\mathrm{SO}_{4} \cdot 5 \mathrm{H}_{2} \mathrm{O}$ ) and presented a $67.1 \%$ of color reduction vs. the $41.0 \%$ reached with the experiment without catalyst at the same experimental conditions $(\mathrm{pH}=5.5$; $[\mathrm{MB}]=$ $100 \mathrm{mg} / \mathrm{L} ; \mathrm{t}=15 \mathrm{~min}$ ). In addition, catalyst dose had a determinant effect on color reduction at $15 \mathrm{~min}$ of reaction time.
From these results, further and deep studies to optimize color reduwction rates as a function on dose and prize of catalyst are proposed as next research steps.

\section{REFERENCES}

[1] G. Eremektar, H. Selcuk and S. Meric, "Investigation of the Relation between COD Fractions and the Toxicity in a Textile Finishing Industry Wastewater: Effect of Preozonation,” Desalination, Vol. 211, No. 1-3, 2007, pp. 314320. http://dx.doi.org/10.1016/j.desal.2006.02.096

[2] European Commission, "Integrated Pollution Prevention and Control (IPPC), Reference Document on Best Available Techniques for the Textiles Industry,” 2003.

[3] A. M. Lotito, U. Fratino, G. Bergna and C. Di Iaconi, "Integrated Biological and Ozone Treatment of Printing Textile Wastewater," Chemical Engineering Journal, Vol. 195-196, 2012, pp. 261-269.

http://dx.doi.org/10.1016/j.cej.2012.05.006

[4] P. Schoeberl, M. Brik, R. Braun and W. Fuchs, “Treatment and Recycling of Textile Wastewater-Case Study and Development of a Recycling Concept,” Desalination, Vol. 171, No. 2, 2005, pp. 173-183. http://dx.doi.org/10.1016/j.desal.2004.02.105

[5] D. Georgiou, J. Hatiras and A. Aivasidis, "Microbial Immobilization in a Two-Stage Fixed-Bed-Reactor Pilot Plant for On-Site Anaerobic Decolorization of Textile Wastewater," Enzyme and Microbial Technology, Vol. 37, No. 6, 2005, pp. 597-605. http://dx.doi.org/10.1016/j.enzmictec.2005.03.019

[6] K. Turhan, I. Durukan, S. A. Ozturkcan and Z. Turgut, "Decolorization of Textile Basic Dye in Aqueous Solution by Ozone," Dyes and Pigments, Vol. 92, No. 3, 2012, pp. 897-901.

http://dx.doi.org/10.1016/j.dyepig.2011.07.012

[7] J. Zhang, K.-H. Lee, L. Z. Cui and T.-S. Jeong, "Degradation of Methylene Blue in Aqueous Solution by OzoneBased Processes," Journal of Industrial and Engineering Chemistry, Vol. 15, No. 2, 2009, pp. 185-189. http://dx.doi.org/10.1016/j.jiec.2008.09.014

[8] C. A. Somensi, E. L. Simionatto, S. L. Bertoli, A. Wisniewski Jr. and C. M. Radetski, "Use of Ozone in a Pilot-Scale Plant for Textile Wastewater Pre-Treatment: Physico-Chemical Efficiency, Degradation By-Products Identification and Environmental Toxicity of Treated Wastewater,” Journal of Hazardous Materials, Vol. 175, No. 1-3, 2010, pp. 235-240. http://dx.doi.org/10.1016/j.clay.2009.08.030

[9] L. Gao, Y. K. Zhai, H. Z. Ma and B. Wang, "Degradation of Cationic Dye Methylene Blue by Ozonation Assisted with Kaolin,” Applied Clay Science, Vol. 46, No. 2, 2009, pp. 226-229. http://dx.doi.org/10.1016/j.clay.2009.08.030

[10] E. Sahinkaya, N. Uzal, U. Yetis and F. B. Dilek, "Biological Treatment and Nanofiltration of Denim Textile Wastewater for Reuse,” Journal of Hazardous Materials, Vol. 153, No. 3, 2008, pp. 1142-1148. http://dx.doi.org/10.1016/j.jhazmat.2007.09.072

[11] R. Liu, H. M. Chiu, C.-S. Shiau, R. Y.-L. Yeh and Y.-T. 
Hung, "Degradation and Sludge Production of Textile Dyes by Fenton and Photo-Fenton Processes," Dyes and Pigments, Vol. 73, No. 1, 2007, pp. 1-6. http://dx.doi.org/10.1016/j.dyepig.2005.10.002

[12] S. Sirianuntapiboon and J. Sansak, "Treatability Studies with Granular Activated Carbon (GAC) and Sequencing Batch Reactor (SBR) System for Textile Wastewater Containing Direct Dyes," Journal of Hazardous Materials, Vol. 159, No. 2-3, 2008, pp. 404-411. http://dx.doi.org/10.1016/j.jhazmat.2008.02.031

[13] C.-H. Wu and H.-Y. Ng, "Degradation of C.I. Reactive Red 2 (RR2) Using Ozone-Based Systems: Comparisons of Decolorization Efficiency and Power Consumption," Journal of Hazardous Materials, Vol. 152, No. 1, 2008, pp. 120-127. http://dx.doi.org/10.1016/j.jhazmat.2007.06.073

[14] S. Karthikeyan, A. Titus, A. Gnanamani, A. B. Mandal and G. Sekaran, "Treatment of Textile Wastewater by Homogeneous and Heterogeneous Fenton Oxidation Processes,” Desalination, Vol. 281, 2011, pp. 438-445. http://dx.doi.org/10.1016/j.desal.2011.08.019

[15] T.-H. Kim, C. Park, J. Lee, E.-B. Shin and S. Kim, "Pilot Scale Treatment of Textile Wastewater by Combined Process (Fluidized Biofilm Process-Chemical Coagulation-Electrochemical Oxidation)," Water Research, Vol. 36, No. 16, 2002, pp. 3979-3988. http://dx.doi.org/10.1016/S0043-1354(02)00113-6

[16] J. B. Parsa and S. H. Negahdar, "Treatment of Wastewater Containing Acid Blue 92 Dye by Advanced OzoneBased Oxidation Methods," Separation and Purification Technology, Vol. 98, 2012, pp. 315-320. http://dx.doi.org/10.1016/j.seppur.2012.06.041
[17] F. Wu, N. S. Deng and H. L. Hua, "Degradation Mechanism of Azo Dye C. I. Reactive Red 2 by Iron Powder Reduction and Photooxidation in Aqueous Solutions," Chemosphere, Vol. 41, No. 8, 2000, pp. 1233-1238. http://dx.doi.org/10.1016/S0045-6535(99)00538-X

[18] H.-Y. Shu and M.-C. Chang, "Decolorization Effects of Six Azo Dyes by O3, UV/O3 and UV/H2O2 Processes," Dyes and Pigments, Vol. 65, No. 1, 2005, pp. 25-31. http://dx.doi.org/10.1016/j.dyepig.2004.06.014

[19] J. R. Domínguez, J. Beltrán and O. Rodríguez, "Vis and UV Photocatalytic Detoxification Methods (Using $\mathrm{TiO}_{2}$, $\mathrm{TiO}_{2} / \mathrm{H}_{2} \mathrm{O}_{2}, \mathrm{TiO}_{2} / \mathrm{O}_{3}, \mathrm{TiO}_{2} / \mathrm{S}_{2} \mathrm{O}_{8}{ }^{2-}, \mathrm{O}_{3}, \mathrm{H}_{2} \mathrm{O}_{2}, \mathrm{~S}_{2} \mathrm{O}_{8}{ }^{2-}$, $\mathrm{Fe}^{3+} / \mathrm{H}_{2} \mathrm{O}_{2}$ and $\mathrm{Fe}^{3+} / \mathrm{H}_{2} \mathrm{O}_{2} / \mathrm{C}_{2} \mathrm{O}_{4}{ }^{2-}$ ) for Dyes Treatment," Catalysis Today, Vol. 101, No. 3-4, 2005, pp. 389-395. http://dx.doi.org/10.1016/j.cattod.2005.03.010

[20] M. S. E. Abdo, H. Shaban and M. S. H. Bader, "Decolorization by Ozone of Direct Dyes in Presence of Some Catalysts," Journal of Environmental Science and Health. Part A: Environmental Science and Engineering, Vol. 23, No. 7, 1988, pp. 697-710. http://dx.doi.org/10.1080/10934528809375444

[21] D. C. Montgomery and G. C. Runger, "Applied Statistics and Probability for Engineers,” 3rd Edition, John Wiley \& Sons, New York, 1999.

[22] R. Jean, “Analisis de las Aguas. Aguas Naturales, Aguas Residuales, Agua de Mar: Quimica, Fisicoquimica, Bacteriologia, Biologia,” Ed. Omega, Barcelona, 1981.

[23] Asociación Española de Normalización y Certificación, "Chemicals Used for Treatment of Water Intended for Human Consumption-Ozone,” UNE-EN 1278, Madrid, 2010, p. 22. 